\title{
Estimation methods of the agricultural equipment value with regard toevaluation of Alina carrot harvester
}

\author{
Zbigniew Kowalczyk ${ }^{1, *}$, Michat Cupiał ${ }^{1}$ \\ ${ }^{1}$ Agricultural University in Krakow, Faculty of Production and Power Engineering, ul. Balicka 116B, 30-149 Kraków, Poland
}

\begin{abstract}
The objective of the paper is to present methods of evaluation of real estates used for evaluation of agricultural equipment and types of value related thereto. Alina carrot harvester by Waremczuk company served as an example, for which a detailed methodology and the results of valuation were presented.

Evaluation was carried out based on two approaches namely a comparative and cost approach. In the case of the comparative approach, the average price adjustment method was used and in the case of the cost approach - a replacement cost method.As a result of using various approaches and methods of evaluation two slightly different values of the evaluated harvester were obtained. It was respectively: EUR16,406 - at the use of the average price adjustment method and EUR 17,678 - the estimated net replacement value in the cost approach for the replacement method.
\end{abstract}

\section{Introduction}

In the developed market economy, one may observe even higher demand for precise estimation of values of technical production means used in agriculture [1]. The objectives of the fixed assets evaluation are varied: to begin with the need to determine the value on account of a possible sale transaction, where a seller and a buyer may be interested parties, and to end with the need to determine the value for the credit or loan guarantee. Besides, the evaluation is carried out in the case of lease contracts concerning fixed assets, insurance, tax, accounting purposes, etc. In relation to the objective and evaluation purpose, varied procedures of estimation are applied. As a result various types of values are obtained. The most popular categories are: the market value and the replacement value, but each of them may be of many types.

In the case of new machines, estimation of their value is not troublesome. However, estimation of used machines is different. With years of exploitation, this exploitation potential gets depleted and thus values of machines decrease as a result of:

- technical wear (physical),

- functional wear (moral),

- external wear (environmental).

The issue of the wear of the agricultural equipment (particularly in the aspect of the value loss) is relatively rarely presented in the scientific literature. This subject has been mentioned by, inter alia, [1-12].
The objective of this paper is to present the most frequently used methods of evaluation of real estatesfor estimation of agricultural devices and the types of value related thereto. Alina carrot harvester by Waremczuk company was used as an example. A detailed methodology of estimation acc. to several methods supported by examples in the form of calculations will be presented.

\section{Material and methods}

The evaluation procedure of a harvester in the comparative approach acc. to the average price adjustment method will be made based on the methodology acc. to the the following stages [4]:

1. Determination of the local market through defining its type, area and the period of investigation of transaction prices.

2. Description of harvesters, which are the object of the market turnover (collected as a consequence of the market analysis) and the evaluated harvester with emphasising their features (attributes).

3. Determination of the type and number of market features which influence the level of prices on the local market along with determination of the weight of market features $\left(\mathrm{k}_{\mathrm{i}}\right), \mathrm{k}_{\mathrm{i}}=\mathrm{r}_{\mathrm{i}}^{2} / \Sigma \mathrm{r}_{\mathrm{i}}^{2},(\mathrm{r}$ - correlation coefficient between market features and prices),

4. Calculation of the average price $\left(\mathrm{C}_{\mathrm{s}}\right)$ based on the representative sample defined earlier (the price bases).

5. Calculation of the correction coefficients value (U) as a quotient of extreme prices to the mean price:

$\mathrm{U}_{\min }=\mathrm{C}_{\min } / \mathrm{C}_{\mathrm{s} \mathrm{r}}$

*Corresponding author: Zbigniew.Kowalczyk@ur.krakow.pl 
$\mathrm{U}_{\max }=\mathrm{C}_{\max } / \mathrm{C}_{\mathrm{s} r}$

6. Calculation of the variability scope of the correction coefficient $\left(\Delta \mathrm{u}_{\mathrm{i}}\right)$ for particular features (attributes):

$\mathrm{k}_{\mathrm{i}} \times \mathrm{U}_{\min } \leq \mathrm{u}_{\mathrm{i}} \leq \mathrm{k}_{\mathrm{i}} \cdot \mathrm{U}_{\max } \Leftrightarrow \Delta \mathrm{u}_{\mathrm{i}}=\mathrm{k}_{\mathrm{i}} \cdot \mathrm{U}_{\max }-\mathrm{k}_{\mathrm{i}} \cdot \mathrm{U}_{\text {min }}$

7. Determination of the maximum scope of scales of particular features (attributes), $\left(\Delta \mathrm{a}_{\mathrm{i}}\right)$ :

$\Delta \mathrm{a}_{\mathrm{i}}=\mathrm{a}_{\max }-\mathrm{a}_{\min }$

8. Calculation of the value of the correction coefficient per a unit of a feature (attribute) of a harvester $\left(\mathrm{u}_{\mathrm{i} / j \mathrm{jed}}\right)$ :

$\mathrm{u}_{\mathrm{i} / j \mathrm{ed}}=\Delta \mathrm{u}_{\mathrm{i}} / \Delta \mathrm{a}_{\mathrm{i}}=\left(\mathrm{k}_{\mathrm{i}} \cdot \mathrm{U}_{\max }-\mathrm{k}_{\mathrm{i}} \cdot \mathrm{U}_{\min }\right) /\left(\mathrm{a}_{\max }-\mathrm{a}_{\min }\right)$

9. Calculation of the difference of the feature of the evaluated harvester and the minimum value of this feature $\left(\Delta \mathrm{a}_{\mathrm{w}-\min }\right)$ :

$\Delta \mathrm{a}_{\mathrm{w}-\min }=\mathrm{a}_{\mathrm{w}}-\mathrm{a}_{\min }$

10. Calculation of the increase of the correction coefficient value for the evaluated harvester in comparison to the minimum value $\left(\mathrm{u}_{\mathrm{i}}\right)$ :

$\mathrm{u}_{\mathrm{i}}=\mathrm{k}_{\mathrm{i}} \cdot \mathrm{U}_{\text {min }}+\Delta \mathrm{a}_{\mathrm{w} \text {-min }} \cdot \mathrm{u}_{\mathrm{i} / \mathrm{jed}}$

11. Calculation of the sum of correction coefficients from all prices $\left(\Sigma \mathrm{u}_{\mathrm{w}}\right)$ :

$\Sigma \mathrm{u}_{\mathrm{w}}=\mathrm{u}_{1}+\mathrm{u}_{2}+\mathrm{u}_{3}+\ldots . . . \mathrm{u}_{\mathrm{n}}$

12. Calculation of the harvester value, which constitutes a product of the average price of a harvester from a representative sample (base) and the sum of correction coefficients $\mathrm{u}_{\mathrm{w}}$

$\mathrm{W}=\mathrm{C}_{\mathrm{s} r} \cdot \sum \mathrm{u}_{\mathrm{w}}$

The procedure for the evaluation of a harvester in the cost approach acc. to the method of replacement costs will be made based on the methodology acc. to the the following stages [7]:

1. Determination of the gross replacement value based on the replacement costs of a new technical mean or the cost of replacing a new technical mean

2. Specification of particular, more important components of the evaluated harvester, assessment of their technical condition and determination of their weights.

3. Determination of the loss of the value of a harvester due to physical reasons (the physical wear),

$$
S_{f z}=\left[1-\sum_{i=1}^{n}\left(\frac{O_{i}}{p_{i}} \cdot w_{i}\right)\right] \cdot 100 \%
$$

where:

$\mathrm{S}_{\mathrm{fz}}-$ physical wear $\%$,

$\mathrm{O}_{\mathrm{i}}-$ obtained grade,

$\mathrm{p}_{\mathrm{i}}-$ the number of points in the scale of grades,

$\mathrm{w}_{\mathrm{i}}-$ weight of a parameter $\mathrm{i}$.
4. Determination of the loss of the value of a harvester dueto internal reasons (the functional wear),

For determination of the degree of the functional wear proportions of changes of technical parameters of the evaluation object and modern, presently manufactured technical means may be helpful e.g. proportions which result from performance, efficiency etc. The above guidelines were used for assessment of particular functional and utility features of a harvester and as a result its functional wear, which finally was estimated acc. to the relation:

$$
S_{f n}=\left[1-\sum_{j=1}^{m}\left(\frac{o_{j}}{p_{j}} \cdot w_{j}\right)\right] \cdot 100 \%
$$

where:

$\mathrm{S}_{\mathrm{fn}} \quad-$ functional wear $\%$,

$\mathrm{o}_{\mathrm{j}} \quad$ - obtained grade,

$p_{j} \quad-$ the number of points in the scale of grades,

$\mathrm{w}_{\mathrm{j}} \quad-$ weight of a parameter $\mathrm{j}$.

5. Determination of the loss of the value of a harvester dueto external reasons (the environmental wear),

6. Calculation of the total loss of the value related to the wear of a harvester

7. Calculation of the net replacement value of a harvester $\mathrm{W}_{\mathrm{N}}=\mathrm{W}_{\mathrm{B}} \cdot\left(1-\mathrm{S}_{\mathrm{fz}}\right) \cdot\left(1-\mathrm{S}_{\mathrm{fn}}\right) \cdot\left(1-\mathrm{S}_{\mathrm{z}}\right)$ EUR

where:

$\mathrm{W}_{\mathrm{N}}$ - net replacement value EUR

$\mathrm{W}_{\mathrm{B}}$ - gross value of a machine EUR,

$\mathrm{S}_{\mathrm{fz}}-$ physical wear,

$\mathrm{S}_{\mathrm{fn}}-$ functional wear,

$\mathrm{S}_{\mathrm{z}}$ - external wear (environmental).

\section{Results and discussion}

Table 1 presents information concerning the market transactions in 2014-2015 including attributes of harevsters and transaction prices. It was found out that the most significant attributes of harvesters, which influence the level of their transaction prices are: age, version, technical condition of sub-assemblies, standard of equipment, origin and a general appearance

\begin{tabular}{|c|c|c|c|c|c|c|c|}
\hline Item & $\begin{array}{c}\operatorname{Age}\left(a_{1}\right) \\
(\text { years) }\end{array}$ & $\begin{array}{c}\operatorname{Version}\left(\mathbf{a}_{2}\right) \\
(1-2)\end{array}$ & $\begin{array}{c}\text { Technical } \\
\text { condition }\left(\mathbf{a}_{3}\right) \\
(0-3)\end{array}$ & $\begin{array}{c}\text { Standard of } \\
\text { equipment } \\
\left(a_{4}\right) \\
(0-3) \\
\end{array}$ & $\begin{array}{l}\left.\text { Origin( } a_{5}\right) \\
\quad(0-2)\end{array}$ & $\begin{array}{c}\text { General } \\
\text { appearance } \\
\left(\mathbf{a}_{\mathbf{6}}\right) \\
(\mathbf{0}-\mathbf{3}) \\
\end{array}$ & $\begin{array}{l}\text { Price } \\
\text { EUR }\end{array}$ \\
\hline 1. & 1 & 2 & 3 & 2 & 2 & 2 & 24,519 \\
\hline 2. & 3 & 1 & 2 & 1 & 2 & 2 & 16,346 \\
\hline 3. & 1 & 2 & 3 & 3 & 2 & 3 & 29,567 \\
\hline 4. & 4 & 2 & 1 & 1 & 1 & 2 & 11,298 \\
\hline
\end{tabular}

Table 1. Information from the local market on the transaction of Alina harvesters by Waremczuk company. 


\begin{tabular}{|c|c|c|c|c|c|c|c|}
\hline 5. & 6 & 2 & 1 & 2 & 1 & 2 & 6,370 \\
\hline 6. & 2 & 1 & 2 & 0 & 2 & 2 & 13,053 \\
\hline 7. & 4 & 1 & 1 & 2 & 0 & 1 & 5,048 \\
\hline 8. & 2 & 2 & 3 & 2 & 1 & 3 & 21,635 \\
\hline 9. & 7 & 1 & 1 & 2 & 2 & 1 & 2,332 \\
\hline 10. & 3 & 1 & 1 & 1 & 2 & 2 & 14,904 \\
\hline 11. & 3 & 2 & 2 & 0 & 1 & 1 & 14,267 \\
\hline 12. & 5 & 1 & 2 & 0 & 2 & 3 & 5,264 \\
\hline 13. & 7 & 2 & 1 & 0 & 2 & 1 & 2,404 \\
\hline 14. & 2 & 2 & 3 & 1 & 2 & 2 & 24,279 \\
\hline 15. & 1 & 1 & 2 & 3 & 0 & 3 & 22,308 \\
\hline 16. & 4 & 1 & 0 & 1 & 0 & 1 & 9,387 \\
\hline 17. & 2 & 2 & 3 & 3 & 2 & 2 & 22,224 \\
\hline 18. & 1 & 2 & 2 & 3 & 1 & 3 & 22,548 \\
\hline 19. & 5 & 1 & 1 & 1 & 2 & 1 & 7,740 \\
\hline 20. & 3 & 2 & 2 & 3 & 1 & 2 & 14,663 \\
\hline 21. & 2 & 2 & 2 & 0 & 1 & 1 & 17,500 \\
\hline 22. & 6 & 1 & 1 & 0 & 0 & 1 & 4,615 \\
\hline 23. & 3 & 2 & 2 & 2 & 1 & 2 & 14,423 \\
\hline 24. & 1 & 2 & 3 & 1 & 2 & 2 & 23,425 \\
\hline 25. & 6 & 1 & 1 & 0 & 2 & 1 & 4,567 \\
\hline 26. & 3 & 2 & 3 & 3 & 2 & 3 & 17,380 \\
\hline 27. & 5 & 1 & 1 & 0 & 0 & 1 & 2,885 \\
\hline 28. & 4 & 1 & 1 & 3 & 1 & 2 & 12,452 \\
\hline 29. & 1 & 2 & 3 & 2 & 2 & 2 & 28,365 \\
\hline 30. & 3 & 1 & 2 & 0 & 1 & 2 & 13,550 \\
\hline Evalua- & $\mathbf{2}$ & $\mathbf{2}$ & $\mathbf{2}$ & $\mathbf{2}$ & $\mathbf{0}$ & $\mathbf{1}$ & $\mathbf{9 ? ?}$ \\
\hline ted & & & & & & & 2 \\
\hline
\end{tabular}

Each of the attributes listed in table 1 was graded in an appropriate scale, which was as follows:

- Age (years)

- Version (1-2): 1- Eco version with lower performance, adjusted to tractors with power 70-90 KM, 2 - Supernova version with higher performance adjusted to tractors with power 90-110 KM

- Technical condition (0-3): 0 - needs major repair, no possibility of use, some sub-assemblies are incomplete or need a major repair 1 - average, a complete harvester, used but needs to be repaired, 2 - good, a harvester is suitable for regular operation, 3 - very good, a new harvester, almost new or after major repair,

- Standard of equipment (0-2): 0 - basic version, 1 - a machine which has additional equipment, 2 - a machine with full additional equipment. A harvester may be additionally equipped with inter alia: haulm catching automatic control module, a conveyor that removes remaining soil from carrots, second direction of conveyor for cleaning crops, rotary haulm gatherers, additional control of a conveyor form a working platform.

- Origin (0-1): 0 - a harvester operated in difficult conditions picking carrot from big acreage, 1 - a combine was used in quite good conditions and picked carrot from small areas.

The impact of attributes on the shaping of the market value was determined with the use of statistical methods, namely the analysis of correlation [6], which is presented in table 2 . 
Table 2. Coefficients of total correlation and their squares as well as percentage share (weights) of their features for explaining variability of prices on the market

\begin{tabular}{|c|c|c|c|c|c|c|}
\hline Specification & Age $\left(\mathrm{a}_{1}\right)$ & Version $\left(\mathrm{a}_{2}\right)$ & $\begin{array}{c}\text { Technical } \\
\text { condition }\left(\mathrm{a}_{3}\right)\end{array}$ & $\begin{array}{c}\text { Standard of } \\
\text { equipment }\left(\mathrm{a}_{4}\right)\end{array}$ & Origin $\left(\mathrm{a}_{5}\right)$ & $\begin{array}{c}\text { General } \\
\text { eqpearance }\left(\mathrm{a}_{6}\right)\end{array}$ \\
\hline $\mathrm{r}_{\mathbf{i}}$ & -0.931 & 0.552 & 0.825 & 0.494 & 0.275 & 0.613 \\
\hline $\mathrm{r}_{\mathrm{i}}{ }^{2}$ & 0.866 & 0.305 & 0.680 & 0.244 & 0.076 & 0.375 \\
\hline $\begin{array}{c}\text { Weight of a } \\
\text { feature \% } \\
\mathbf{k}_{\mathbf{i}}=\mathbf{r}_{\mathbf{i}}{ }^{2} / \Sigma \mathbf{r}_{\mathbf{i}}{ }^{2}\end{array}$ & $\mathbf{- 3 4 . 0}$ & $\mathbf{1 2 . 0}$ & $\mathbf{2 6 . 7}$ & $\mathbf{9 . 6}$ & $\mathbf{3 . 0}$ & $\mathbf{1 4 . 7}$ \\
\hline
\end{tabular}

One of the evaluation methods as a part of the comparative approach is the average prices adjustment method. In this method the market analysis and data presented in tables 1 and 2 were used.

According to the formula presented in the methodology, the value of the correction coefficients
(U) constitutes a quotient of extreme prices and the average price:

$\mathrm{U}_{\min }=\mathrm{C}_{\min } / \mathrm{C}_{\mathrm{sr}}=\mathrm{EUR} 2,332 /$ EUR14,311 $=0.1629$

$\mathrm{U}_{\max }=\mathrm{C}_{\max } / \mathrm{C}_{\mathrm{sr}}=\mathrm{EUR} 29,567 / \mathrm{EUR} 14,311=2.0660$

Evaluation procedure was presented in table 3 .

Table 3. Evaluation of Alina harvester acc. to the average price adjustment method

\begin{tabular}{|c|c|c|c|c|c|c|}
\hline Specification & $\operatorname{Age}\left(a_{1}\right)$ & Version $\left(\mathbf{a}_{2}\right)$ & $\begin{array}{c}\text { Technical } \\
\text { condition }\left(a_{3}\right)\end{array}$ & \begin{tabular}{|c|} 
Standard of \\
equipment $\left(a_{4}\right)$
\end{tabular} & Origin(a) & $\begin{array}{c}\text { General } \\
\text { appearance } \\
\left(\mathrm{a}_{6}\right) \\
\end{array}$ \\
\hline Weight of a feature: $\mathrm{k}_{\mathrm{i}}(\%)$ & $34.0^{*}$ & 12.0 & 26.7 & 9.6 & 3.0 & 14.7 \\
\hline $\mathrm{k}_{\mathrm{i}} \cdot \mathrm{U}_{\min }$ & 0.0544 & 0.0195 & 0.0435 & 0.0156 & 0.0048 & 0.0240 \\
\hline $\mathrm{k}_{\mathrm{i}} \cdot \mathrm{U}_{\max }$ & 0.7026 & 0.2475 & 0.5519 & 0.1983 & 0.0614 & 0.3045 \\
\hline Spread of attributes: $\Delta \mathrm{a}_{\mathrm{i}}$ & 6 & 1 & 3 & 3 & 2 & 2 \\
\hline $\begin{array}{l}\text { Value of the correction } \\
\text { coefficient per a unit of a } \\
\text { feature: } \mathrm{u}_{\mathrm{i} / \mathrm{jed}}\end{array}$ & 0.108 & 0.228 & 0.169 & 0.061 & 0.028 & 0.140 \\
\hline $\begin{array}{l}\text { Attributes of the evaluated } \\
\text { harvester: } a_{w}\end{array}$ & 2 & 2 & 2 & 0 & 1 & 3 \\
\hline $\begin{array}{l}\text { Difference in attributes of } \\
\text { the evaluated harvester and } \\
\text { the minimum attribute: } \Delta \mathrm{a}_{\mathrm{w}-} \\
\text { min }\end{array}$ & 1 & 1 & 2 & 0 & 1 & 2 \\
\hline $\begin{array}{l}\text { Increase of the correction } \\
\text { coefficient towards the } \\
\text { minimum value: } \mathrm{u}_{\mathrm{i}}\end{array}$ & 0.163 & 0.247 & 0.382 & 0.016 & 0.033 & 0.304 \\
\hline $\mathrm{W}$ & \multicolumn{2}{|c|}{16,406 EUR } & & & & \\
\hline
\end{tabular}

where * - negative correlation

The second approach acc. to which evaluation of the particular harvester was made is the cost approach and the applied method is called a replacement method. The gross replacement value was determined based on prices of brand new harvesters on the original market. The value of a harvester with an identical additional equipment is $\mathrm{W}_{\mathrm{B}}=$ EUR31,490.

In this paper, a technical condition of agricultural equipment was assessed based on the detailed inspection and interview with an owner and sometimes with other users.

During determination of the physical wear of a harvester, a condition of each of more important subassemblies was assessed. Weights for particular sub- assemblies were also determined taking into consideration the participation of the replacement costs of sub-assemblies in the total cost of the object and observed preferences of possible purchasers on the market (table no. 4)

Each object (sub-assembly) of the evaluated harvester was assessed from 0 to 3 , where:

0 - a technical condition of a particular sub-assembly rendered the regular machine operation impossible and a sub-assembly required a general renovation (or possibly a replacement),

1 - average condition, degree of wear of a sub-assembly makes the machine operation possible but a subassembly should be repaired, 
2 - good condition - without any bigger traces of wear, possibly a sub-assembly after repair

3 - very good condition - a new sub-assembly or almost new, without traces of use.

Table 4. Sub-assemblies of a harvester, their price and ordered weights

\begin{tabular}{|c|l|c|c|}
\hline Item & \multicolumn{1}{|c|}{ Sub-assembly } & $\begin{array}{c}\text { Weight } \\
\text { \% }\end{array}$ & $\begin{array}{c}\text { Grade } \\
\mathbf{( 0 - 3 )}\end{array}$ \\
\hline 1. & $\begin{array}{l}\text { Frame and driving } \\
\text { system }\end{array}$ & 20 & 2 \\
\hline 2. & $\begin{array}{l}\text { Ploughing and } \\
\text { topping unit }\end{array}$ & 30 & 2 \\
\hline 3. & $\begin{array}{l}\text { Separating and } \\
\text { loading unit }\end{array}$ & 35 & 2 \\
\hline 4. & Hydraulic system & 15 & 3 \\
\hline
\end{tabular}

Based on the obtained description of the technical condition of a harvester, thephysical wear was calculated (according to the formula presented in methodology) which is: $\mathrm{S}_{\mathrm{fz}}=28.3 \%$

Table 5. Functional and utility features of a harvester, their price and ordered weights

\begin{tabular}{|l|l|c|c|}
\hline Item & \multicolumn{1}{|c|}{ Sub-assembly } & $\begin{array}{c}\text { Weight } \\
\text { \% }\end{array}$ & $\begin{array}{c}\text { Grade } \\
(\mathbf{0 - 3})\end{array}$ \\
\hline 1. & Performance & 30 & 2 \\
\hline 2. & Power demand & 15 & 2 \\
\hline 3. & Failure frequency & 20 & 2 \\
\hline $4 /$ & Availability of spare & 20 & 3 \\
\hline 5. & Simplicity of operation & 15 & 3 \\
\hline
\end{tabular}

The functional wear of a harvester was determined according to the relation presented in the methodology and it is: $\mathrm{S}_{\mathrm{fn}}=21.7 \%$.

The degree of wear due to the external reasons may not appear and in case of the evaluated harvester - did not occur.

Net replacement value of a harvester was calculated acc. to the formula presented in the methodology and finally it was: $\mathrm{W}_{\mathrm{N}}=\mathrm{EUR} 17,678$

\section{Closing remarks}

The paper herein includes two approaches used in the evaluation of technical fixed assets, namely: the comparative approach and the cost approach. The comparative approach is used for determination of the market value of machines and devices only when the objects similar to the object, which is the subject of evaluation, were in the turnover on the determined market in the period of the last two years, preceding the evaluation and also when their prices and features, which influence those prices and conditions for transactions are known.

The cost approach is based on the assumption that the purchaser, which is aware, so-called informed and oriented in the market conditions, will not pay more for a technical mean than the manufacture cost of the substituting mean of the same utility as the evaluated one. This approach assumes that the amount equal to the price of construction of a new object of the same utility is the maximum value of the technical mean.

A market value - constitutes the most probable price which may be obtained on the market when the following assumptions have been made:

a) the parties to the contract do not depend on each other and act rationally without any specific motives,

b) intend to conclude a contract,

c) are aware of the co-existing circumstances which have an impact on the value of the transaction object,

d) do not act in forced circumstances,

e) period of indispensable exposure of the object on the market with the use of appropriate advertisement and the time needed for negotiation of the contract conditions have lapsed, taking into account the nature of the real estate and the market condition.

The replacement value reflects the cost of manufacturing of a substitutive mean of the same utility as the evaluated mean.

The marked value of the evaluated harvester in the average price adjustment method is: EUR 16,406. The evaluated net replacement value in the cost approach, the replacement method is EUR17,678 and is close to the market value obtained in calculations.

The procedures used in the paper may be used for estimation of the value of machines, tools and agricultural devices.Due to the used methodology, a result obtained in case of the average price adjustment method, which is generally used in case of a higher number of market transactions, is more precise. In case, there is no sufficient number of market transactions a method different than a statistical one shall be used for determination of weights of attributes of the evaluated objects.

The procedures used in the paper may be used for estimation of the value of machines, tools and agricultural devices.

\section{References}

1. Z. Kowalczyk, Inżynieria Rolnicza, 6(94) 89-95 (2007)

2. Z. Grześ, Prace Przemysłowego Instytutu Maszyn Rolniczych, 1, 84-85 (2001)

3. J. Borcz, Z. Kowalczyk, Inżynieria Rolnicza, 6, 49$56(2005)$

4. J. Borcz, Z. Kowalczyk, Inżynieria Rolnicza, 6, 5763 (2005)

5. J. Borcz, Z. Kowalczyk, Inżynieria Rolnicza, 11, 7783 (2006)

6. Z.Kowalczyk, Inżynieria Rolnicza, 9(107), 151-156 (2008)

7. Z. Kowalczyk, The level and the structureof the wear of technical production means in different types of agricultural farms, Rozprawa habilitacyjna, Inżynieria Rolnicza, 2,(2011) 
8. R. Michalski, J. Napiórkowski, Technical Sciences. University of Warmia and Mazury in Olsztyn, 1: 139-147(2004)

9. J. Borcz, J. Kosek, Estimation methods of machines' value, Vademecum Rzeczoznawcy majątkowego, Kraków,(1994)

10. H. Macniak, Z. Makowicz, Vademecum of the machines' valuation, PFSRM, Gdańsk, (1996)

11. J. Napiórkowski, R. Źróbek, Estimation methods of machines' value, Zachodnie Centrum Organizacji, Zielona Góra,(2001)

12. T. Klimek, Valuation of the machines. Stowarzyszenie Rzeczoznawców Majątkowych w Katowicach,Katowice, (1995) 